\title{
CONTRIBUTION TO A ROCK BLOCK SLIDE EXAMINATION BY A MODEL OF MUTUAL TRANSFORMATION OF POINT CLOUDS
}

\author{
PRISPEVEK K PREVERJANJU ZDRSA SKALNEGA BLOKA \\ Z MODELOM MEDSEBOJNE PRESLIKAVE OBLAKOV TOČK
}

\author{
Sebastjan KONIČ ${ }^{1}$, Mihael RIBIČIČํํㄹ \& Milivoj VULIĆ ${ }^{1}$
}

\begin{abstract}
UDC 622.02

Sebastjan Konič, Mihael Ribičič \& Milivoj Vulić: Contribution to a rock block slide examination by a model of mutual transformation of point clouds

Basic objective of this article is to find out whether the rock block on which the castle of Črni kal is situated sticked once to the Kraški rob wall. The result is given on the basis of comparison of forms of both presumed contact surfaces represented by a great number of points determined in space. This cloud of points has been captured by 3D terrestrial laser scanning. On the basis of assessment of geological and morphological characteristics of the Črni kal rock block and the Kraški rob wall 12 characteristic pairs of corresponding (matching) points were collected, one pair consisting of two points, each from its own wall. By use of a method called 12-parameter affine transformation, transformation parameters of one cloud transformation into the other one were calculated. Since for such a transformation 4 pairs of points are enough, and there were even 12 pairs of points used in order to provide better results, the socalled least square method (LSM) was used. By the so obtained transformation vector the reference point cloud of the Črni kal rock block was transformed, for a size of the vector move back, into a cloud of transformed points which should match the reference point cloud of the Kraški rob wall. The comparison of a reference point cloud of Kraški rob and a cloud of transformed points showed that the rock block of Črni kal slid in a S-SW direction for $4.7 \mathrm{~m}$ in form of a block failure. Static analysis of matching point clouds proved that as much as $95 \%$ of points fell within a distance less than $0.74 \mathrm{~m}$ which confirmed the hypothesis that the rock block on which the castle of Črni kal was situated represented once a part of the Kraški rob wall. Prior to the $11^{\text {th }}$ century at least, it split away from it and moved parallel to the wall in form of a block failure.

Keywords: rock block slide, locating characteristic pairs of corresponding point entities, 12-parameter affine transformation, rotation-deformation matrix, translation vector.
\end{abstract}

Izvleček

UDK 622.02

Sebastjan Konič, Mihael Ribičič \& Milivoj Vulić: Prispevek $k$ preverjanju zdrsa skalnega bloka $z$ modelom medsebojne preslikave oblakov točk

Osnovni cilj članka je ugotoviti ali se je skalni blok, na katerem stoji grad Črni kal, nekoč stikal s steno Kraškega roba. Ugotovitev se podaja na osnovi izdelave primerjave oblike obeh morebitnih stičnih ploskev, ki sta predstavljeni z velikim številom $\mathrm{v}$ prostoru določenih točk. Ta oblak točk je bil zajet $\mathrm{s}$ 3D terestričnim laserskim skeniranjem. Na podlagi ugotavljanja geoloških in morfoloških značilnosti skalnega bloka Črni kal in stene Kraškega roba je bilo zbrano 12 karakterističnih parov korespodentnih (ustreznih) točk, $\mathrm{v}$ parih po ena iz vsake stene. $\mathrm{Z}$ uporabo metode afine 12 parametrične preslikave so bili izračunani transformacijski parametri preslikave enega oblaka v drugega. Ker so za to preslikavo dovolj 4 pari točk, za boljše rezultate pa je bilo uporabljenih 12 parov točk, je bila zaradi večjega števila parov točk uporabljena metoda najmanjših kvadratov (MNK). S pomočjo tako dobljenega transformacijskega vektorja je bil referenčni oblak točk skalni blok Črni kal preslikan za velikost vektorskega premika nazaj v oblak transformiranih točk, ki naj bi se prekrival z referenčnim oblakom točk stene Kraškega roba. Primerjava referenčnega oblaka točk Kraški rob in oblaka preslikanih transformiranih točk je pokazala, da je skalni blok Črni kal kot blokovni plaz zdrsnil za $4,7 \mathrm{~m}$ v smeri S-SW. Statistična analiza prekrivajočih se oblakov točk je pokazala, da kar $95 \%$ točk pade v razdaljo manjšo od $0,74 \mathrm{~m}$, kar potrjuje postavljeno hipotezo, da je bil skalni blok na katerem stoji grad Črni kal nekoč del stene Kraškega roba, od katere se je najmanj pred 11. stoletjem odtrgal in se vzporedno premaknil kot blokovni plaz.

Ključne besede: zdrs skalnega bloka, lociranje karakterističnih parov korespodentnih točkovnih entitet, afina 12 parametrična transformacija, rotacijsko-deformacijska matrika, translacijski vektor.

\footnotetext{
${ }^{1}$ University of Ljubljana, Faculty of Natural Sciences and Engineering, Aškerčeva 12, SI- 1000 Ljubljana, Slovenia, e-mail: mihael.ribicic@ntf.uni-lj.si
}

Received/Prejeto: 17.11.2008 


\section{INTRODUCTION}

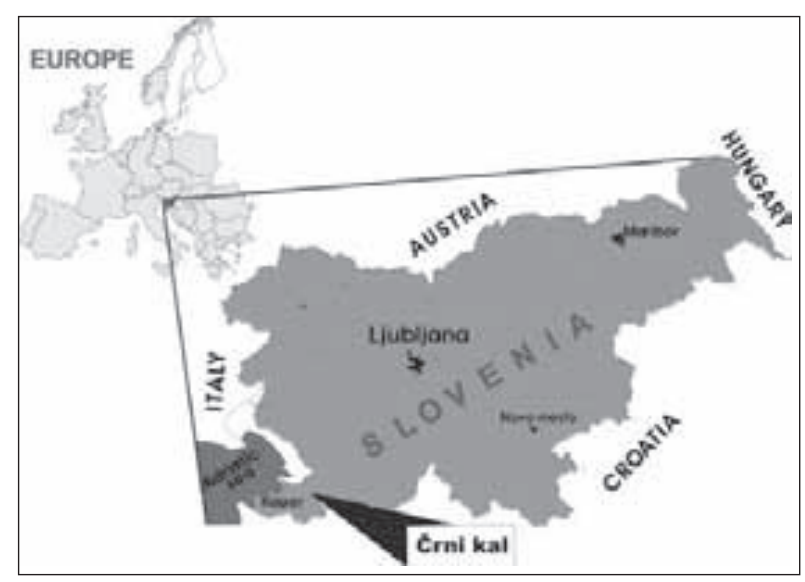

Fig. 1: Map of Slovenia with the point denoting the location of the study.

The rock block on which the castle of Črni kal is situated lies in the Kraški rob area (Konič 2008). In this article, the term of »Kraški rob« is exclusively used to define a carbonate wall overhanging above the Črni Kal village which was formed as a result of the Adriatic - Apulian foothills thrusting underneath the External Dinarides (Placer 2007).

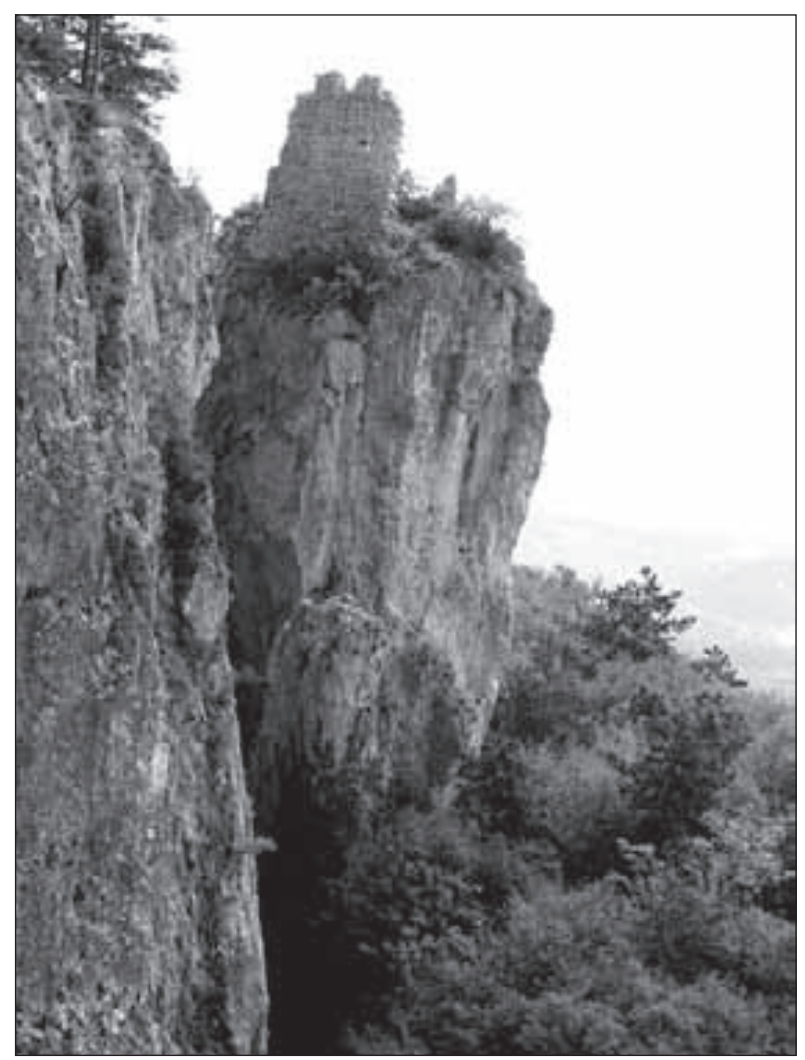

Fig. 2: Photo of the "Kraški rob wall « and the rock block whereon the castle of Crni kal is situated (Photo: M. Ribičič).
A preliminary visit serving to explore the rock block whereon the castle of Črni kal is situated indicated a possible rock block slide away from the Kraški rob wall (Ribičič 2004). In order to prove the initial assumptions it was determined to scan both rear walls (slope surfaces) by use of a 3D terrestrial laser scanning and in continuation, to perform a mutual comparison of both walls forms by electronic data processing.

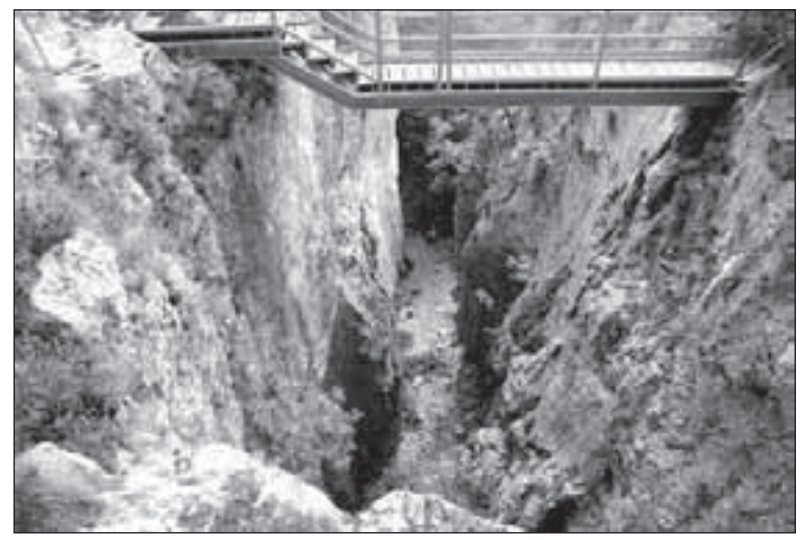

Fig. 3: Photo of the "Kraški rob wall on the left, and the rock block »Črni kal« on the right (Photo: M. Ribičič).

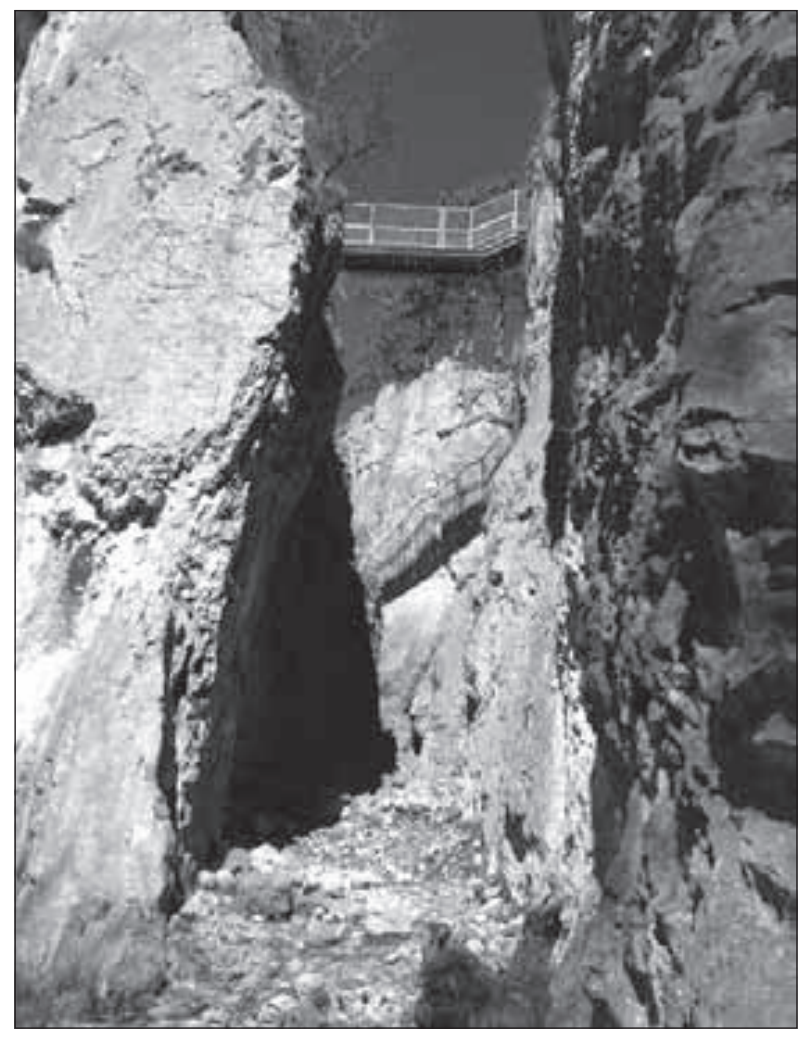

Fig. 4: Photo of the »Kraški rob wall« on the right, and the rock block "Črni kal« on the left (Photo: S. Konič). 


\section{MATERIALS AND METHODS}

For examination of the slide of a rock block whereon the castle of Črni kal is situated the 3D terrestrial laser scanning method was used for data (point clouds) acquisition. The RIEGEL LMS-Z420i 3D terrestrial laser scanner system with associated operating and processing software Riscan Pro (RIEGL Laser Measurement Systems 2008) was used as well.

Laser scanning of the treated area was performed by the company of Geodetic Institute Celje d.o.o. By scanning of both rear walls four scan positions were used whereby six individual scanograms were made and fifteen uniformly disposed fix tie points were determined, on the basis of which individual scanograms were combined into one joint scanogram after scanning was accomplished (Fig. 5).

This was followed by a selection of 12 characteristic pairs of corresponding points obtained as a result of an assessment of morphological and geological characteristics of the Črni kal rock block and the Kraški rob wall. An example of mutually corresponding points, which shall stick together prior to the slide, is given in the two figures here below.

The Point 1 taken from the system (cloud) of points - rock block of $\check{C}$ rni kal was selected in a recess defined by stratification and cracks spreading perpendicular to it.

A corresponding, matching point 1 taken from the system (cloud) of points - Kraški rob wall was selected on a convexity of the eastern part of the treated area. This point was located in a limestone with high frequen-

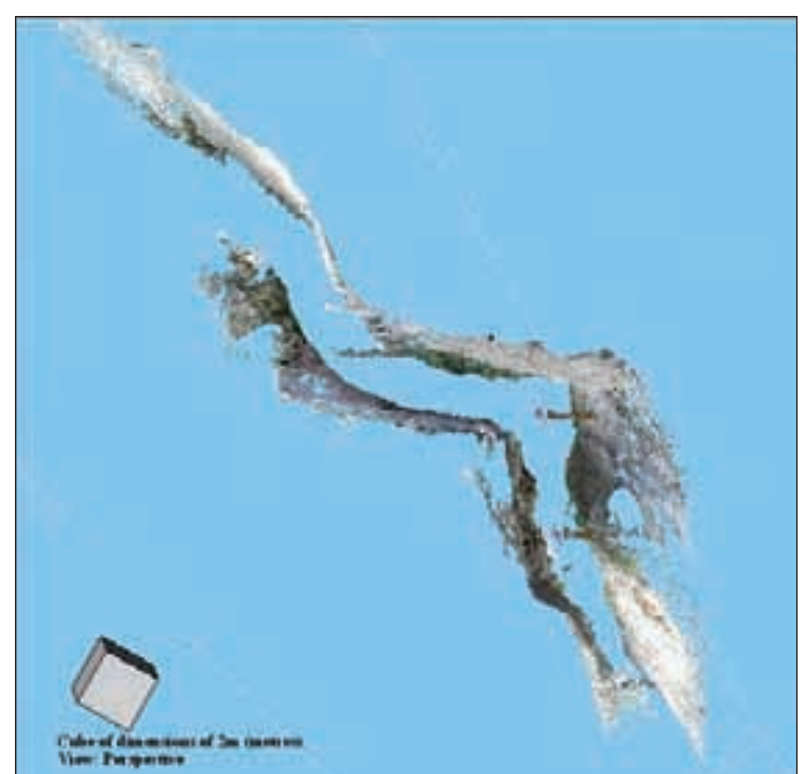

Fig. 5: Presentation of a combined (joint) scan; Kraški rob wall on the right and the wall with the Crrni kal castle on the left. cy of joints. The convexity sprang up at the intersection of a stratification system and a system of perpendicular cracks.

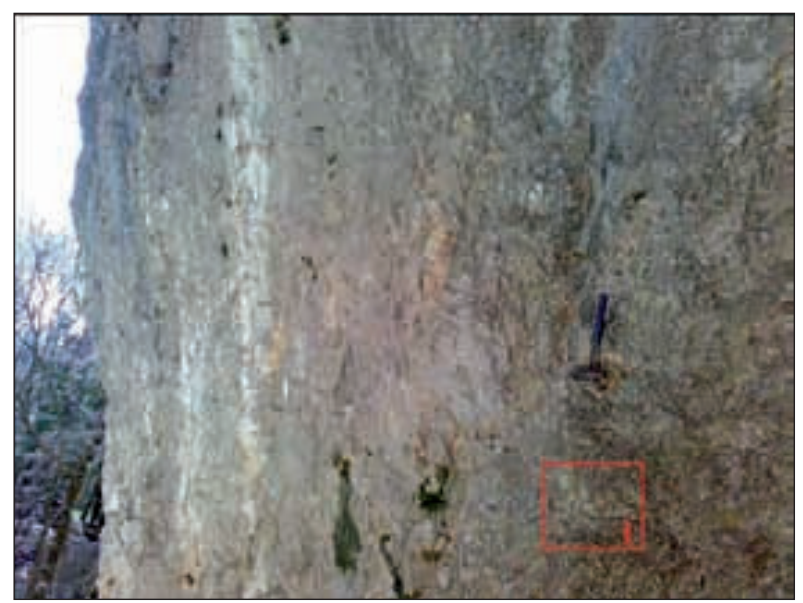

Fig. 6: Point 1 from the system (cloud) - rock block of Črni kal (Photo: S. Konič).

The other pairs of corresponding (matching) point entities were selected according to similar geological, morphological, geometrical and other measuring criteria.

By use of 12-parameter affine transformation method (Toth \& Shan 2008) the following transformation parameters were calculated:

1. Rotation-deformation matrix:

$$
\mathbf{M}=\left[\begin{array}{lll}
\mathbf{M}_{\mathbf{x}, \mathrm{X}} & \mathbf{M}_{\mathrm{x}, \mathrm{Y}} & \mathbf{M}_{\mathrm{x}, \mathrm{Z}} \\
\mathbf{M}_{\mathbf{y}, \mathrm{Y}} & \mathbf{M}_{\mathbf{y}, \mathbf{Y}} & \mathbf{M}_{\mathbf{y}, \mathrm{Z}} \\
\mathbf{M}_{z, \mathrm{X}} & \mathbf{M}_{\mathrm{z}, \mathrm{Y}} & \mathbf{M}_{\mathrm{z}, \mathrm{Z}}
\end{array}\right.
$$

2. Translation vector:

$$
\mathrm{T}=\left[\begin{array}{l}
\mathrm{T}_{\mathrm{x}}^{-} \\
\mathrm{T}_{\mathrm{y}} \\
\mathbf{T}_{\mathrm{z}_{-}}
\end{array}\right.
$$

By use of the translation vector the point cloud of the Črni kal castle wall was transformed back into its presumed original position before its slide from the Kraški rob wall (Vižintin et al. 2008).

Since for such a transformation 4 pairs of points are enough, and there were even 12 pairs of points used in order to provide better results, the so-called least square method (LSM) was used (Vulić 2007b). 


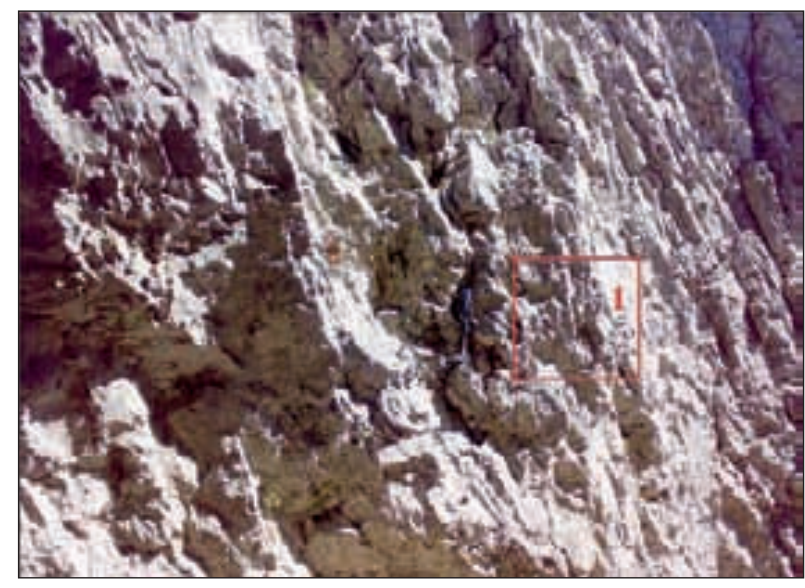

Fig. 7: Point 1 from the system (cloud) - Kraški rob wall (Photo: S. Konič).

The result of the transformation parameters calculation as well as the transmission to all points, including the 12 pairs of corresponding points (Vulić 2006/2007), is given in the Fig. 8 .
By calculated transformation parameters (Milivoj Vulić 2008a) a transformation of the reference system (cloud) of points Črni kal rock block was then calculated in the Kraški rob reverse direction.

The transformation equation of any individual point i, for transformation of points from the system (cloud) of Črni kal rock block into a system (cloud) of Kraški rob wall, is expressed by two matrix equations (Vulić 2007a):

$$
\underset{3 x 1}{x_{i}^{\prime}}=\underset{3 x 3}{M} \cdot \underset{3 x 1}{X_{i}}+\underset{3 x 1}{T}
$$

Or in a developed form:

Legend of Fig. 8:

Points from the system (cloud) of Črni kal rock block

Points from the system (cloud) of Kraški rob wall

12 corresponding (matching) points from the system (cloud) Kraški rob wall

12 corresponding (matching) points from the system (cloud) Črni kal rock block

Line connections of 12 pairs of corresponding points
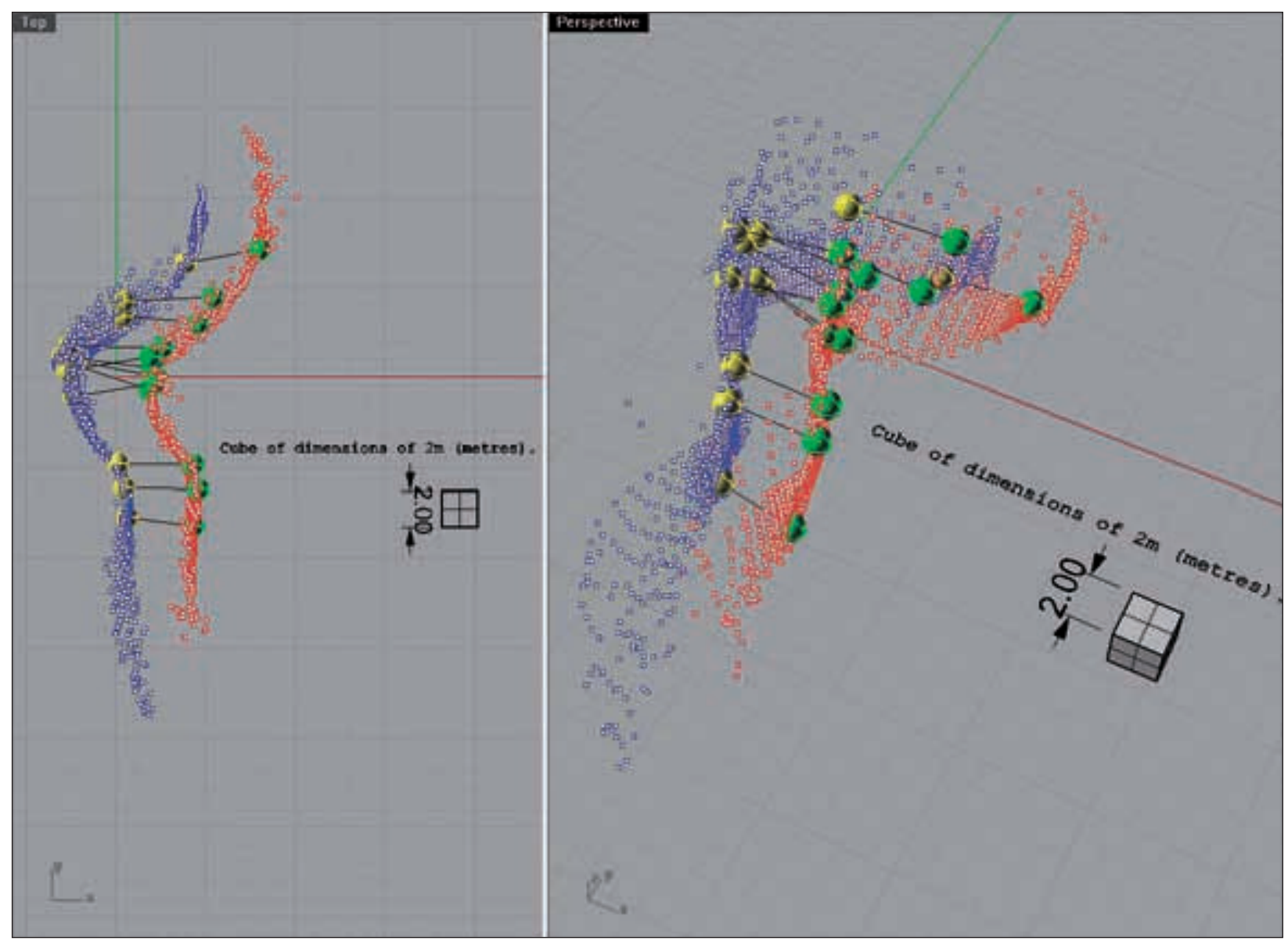

Fig. 8: Graphic presentation of point clouds obtained by laser scanning and selected 12 pairs of corresponding (matching) points. 

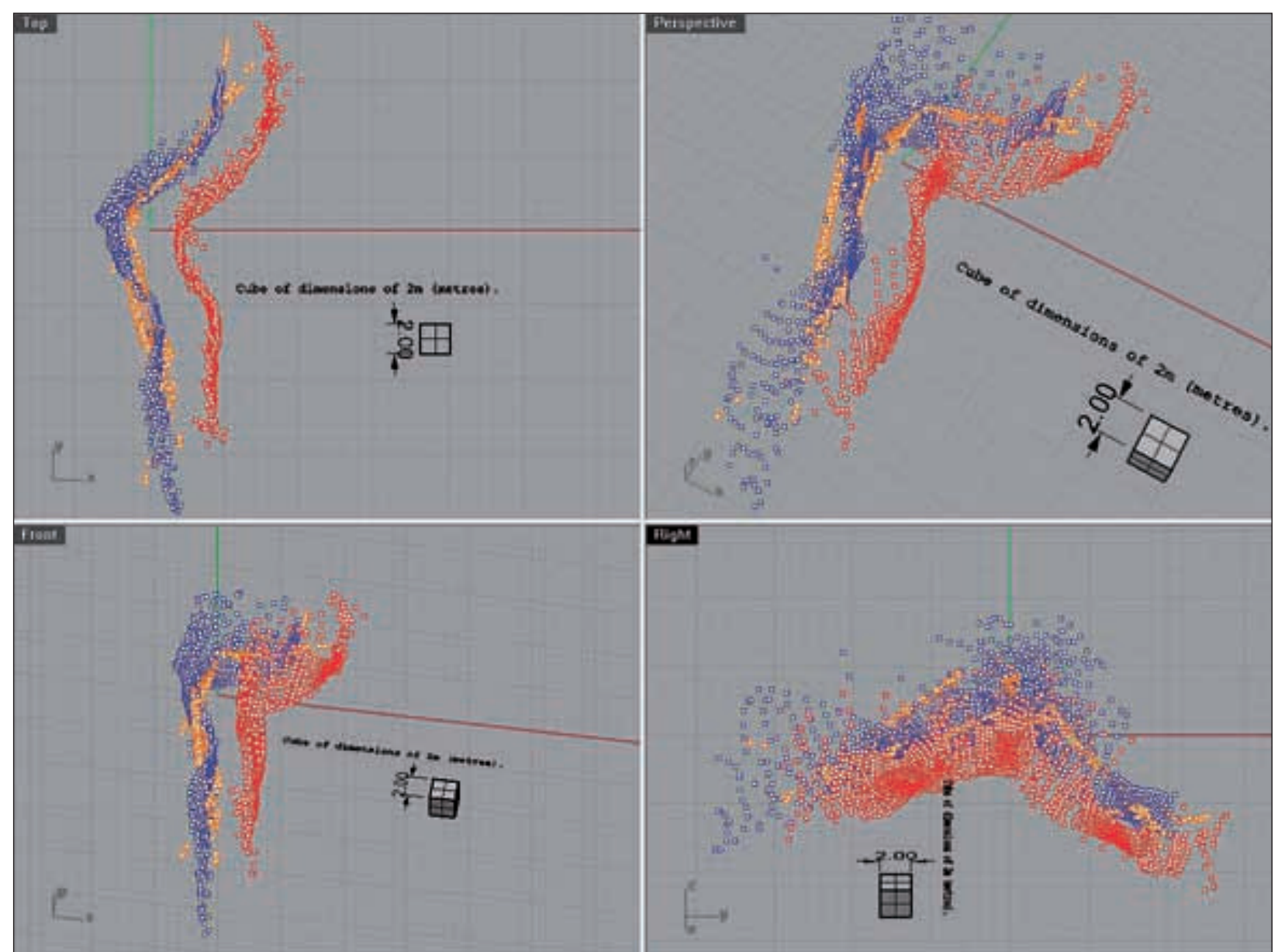

Fig. 9: Comparison of transformed and reference point clouds in the Rhinoceros Program.

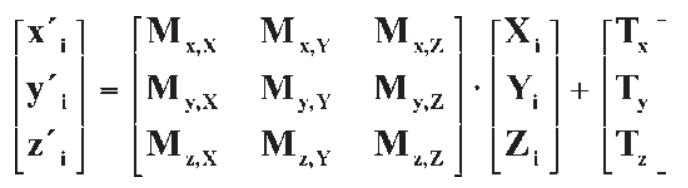

After the reference system (cloud) of Črni kal rock block points transformation was accomplished (Milivoj Vulić 2008b), a comparison of the system (cloud) of transformed points with a reference system (cloud) of Kraški rob wall points was made. The comparison of the transformed and the reference point clouds was made and presented graphically by two software tools used for space modelling called Rhinoceros and Geomagic Studio.
Legend of Fig. 9:

Point cloud from the system - Črni kal rock block

Point cloud from the system - Kraški rob wall

Cloud of transformed (calculated) points 


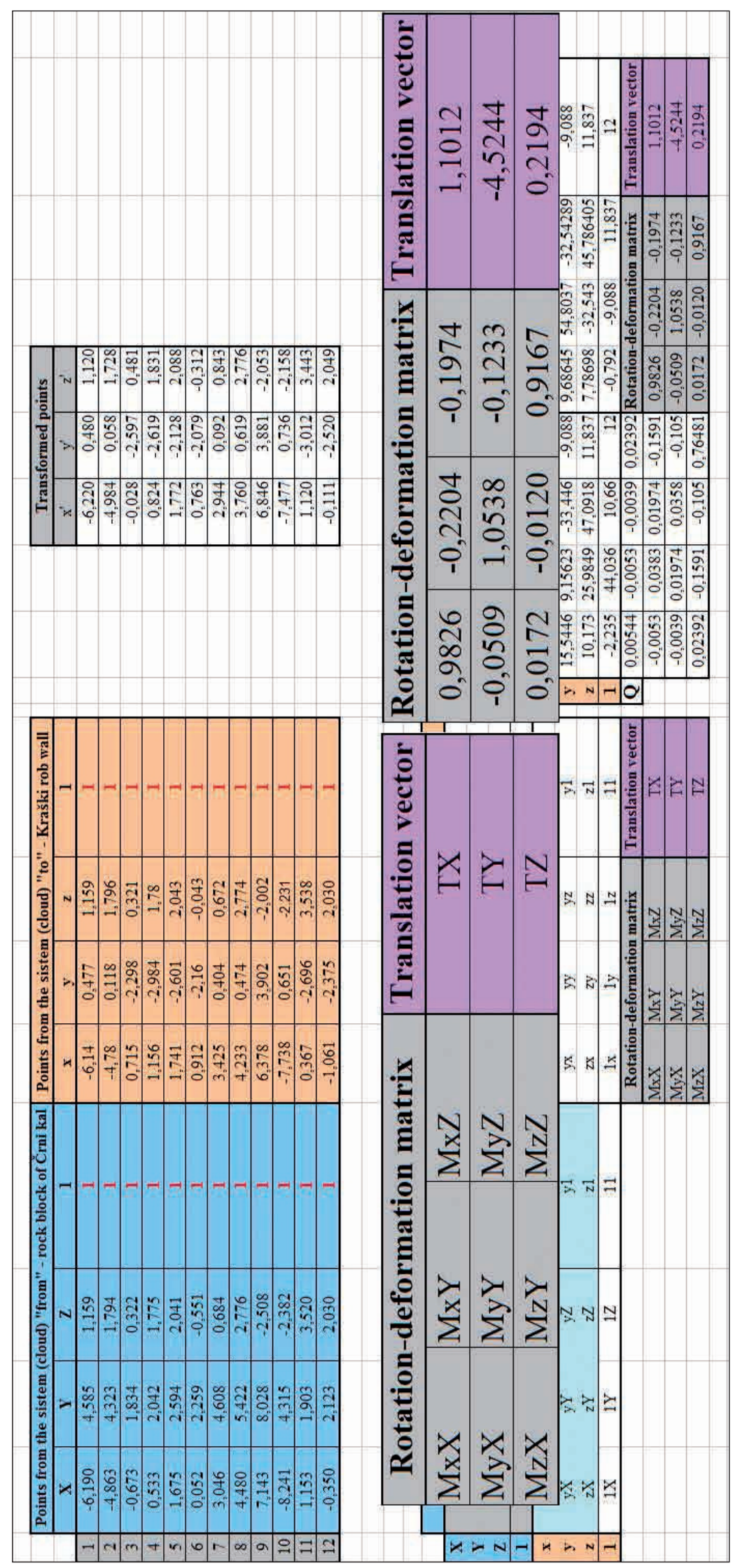

Tab. 1: Calculation of transformation parameters (rotation-deformation matrix and translation vector) by use of 12- parameter affine transformation method. 


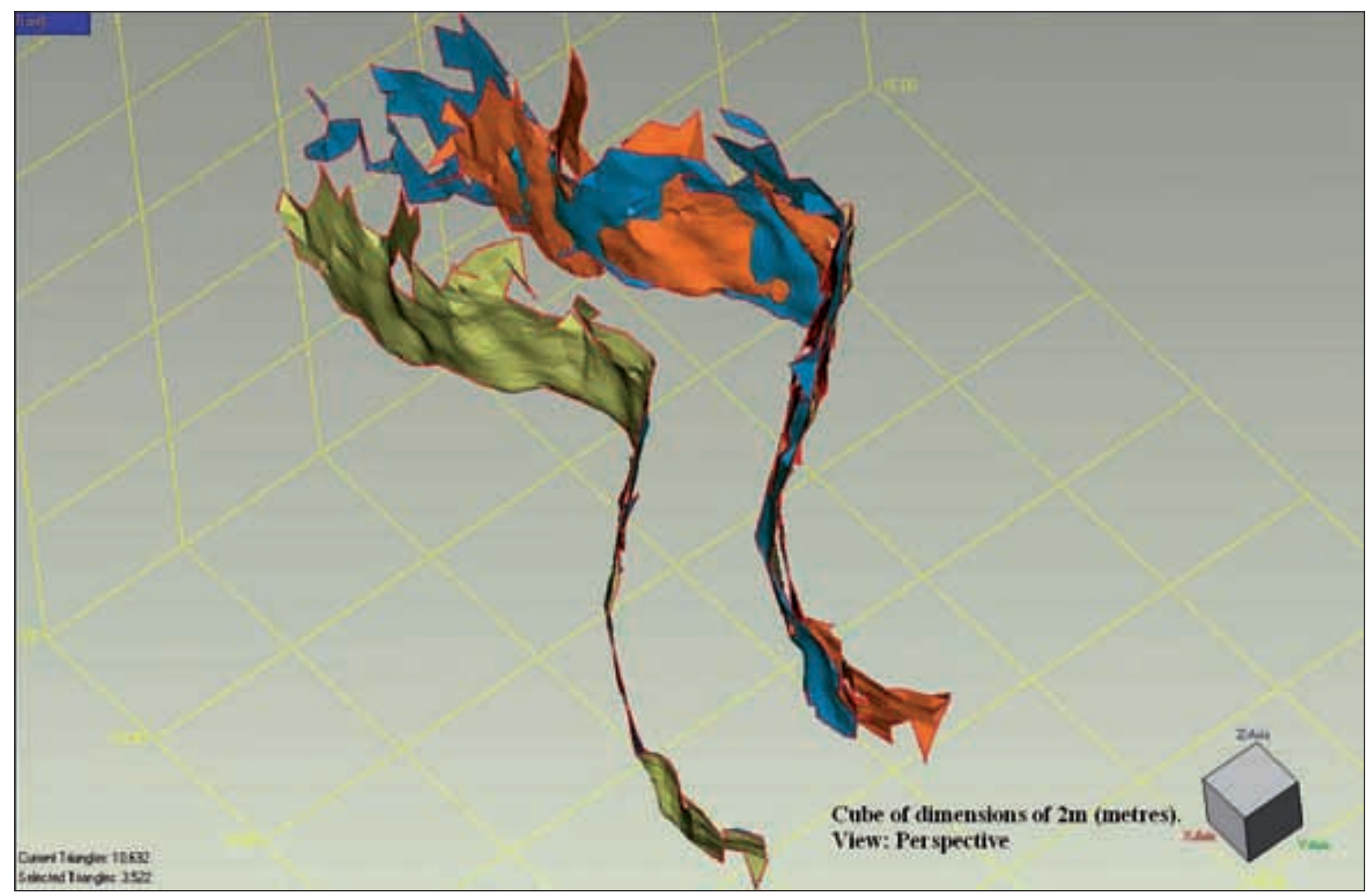

Fig. 10: Presentation of surfaces of all three triangulated systems (clouds) of points in the Geomagic Studio program.

Legend of Fig. 10:

$\square$ Triangulated surface of the system (cloud) of points - Črni kal rock block

Triangulated surface of the system (cloud) of points - Kraški rob wall

Triangulated surface of the system (cloud) of transformed points

\section{RESULTS AND DISCUSSION}

From the Figs. 9 and 10 a good matching of the transformed system (cloud) of points with the reference system (cloud) of points - Kraški rob wall can be observed, which proves the initial hypotheses that the Črni kal rock block once made part of the Kraški rob wall wherefrom it slid in form of a rock block slide. This was proved also by a statistical analysis of twelve pairs of corresponding points and matching point clouds.

Further on, a calculation of an average standard deviation of transformation was added to the comparison of the transformed system (cloud) of points with the reference cloud of points - Kraški rob wall. The standard deviation of 12 pairs of corresponding points transformation was calculated in the Excel program. For com- parison reasons, a calculation of an average standard deviation of the whole transformed points system (cloud) transformation made in the Geomagic Studio program was added.

The calculated average standard deviation of 12 pairs of corresponding points transformation made according to a method developed at KRMGR and KAG and performed in the Microsoft Excel program amounts to $0.38 \mathrm{~m}$. 


\begin{tabular}{|c|c|c|c|c|c|c|c|c|c|c|}
\hline$-0,033$ & 0 & & 0,028 & 0 & 0 & 0,009 & 0 & 0 & 0,259 & \multirow[b]{3}{*}{0,448} \\
\hline 0 & $-0,033$ & 0 & 0 & 0,028 & 0 & 0 & 0,009 & 0 & 0,259 & \\
\hline 0 & 0 & $-0,033$ & 0 & 0 & 0,028 & 0 & 0 & 0,009 & 0,259 & \\
\hline 0,014 & 0 & 0 & $-0,024$ & 0 & 0 & $-0,014$ & 0 & 0 & 0,353 & \multirow[b]{3}{*}{0,612} \\
\hline 0 & 0,014 & 0 & 0 & $-0,024$ & 0 & 0 & $-0,014$ & 0 & 0,353 & \\
\hline 0 & 0 & 0,014 & 0 & \multicolumn{2}{|c|}{$\begin{array}{rr}0 & -0,024\end{array}$} & 0 & \multicolumn{2}{|c|}{$0-0,014$} & 0,353 & \\
\hline 0,095 & 0 & 0 & $-0,025$ & 0 & 0 & 0,000 & 0 & 0 & 0,309 & \multirow[b]{3}{*}{0,535} \\
\hline 0 & 0,095 & 0 & 0 & $-0,025$ & 0 & 0 & 0,000 & 0 & 0,309 & \\
\hline 0 & 0 & 0,095 & 0 & 0 & $-0,025$ & 0 & 0 & 0,000 & 0,309 & \\
\hline$-0,025$ & 0 & & 0,044 & 0 & 0 & 0,028 & 0 & 0 & 0,209 & \\
\hline 0 & $-0,025$ & 0 & 0 & 0,044 & 0 & 0 & \multirow{2}{*}{$\begin{array}{r}0,028 \\
0\end{array}$} & 0 & 0,209 & \multirow[b]{2}{*}{0,361} \\
\hline 0 & 0 & $-0,025$ & 0 & 0 & 0,044 & 0 & & 0,028 & 0,209 & \\
\hline 0,000 & 0 & 0 & 0,028 & 0 & 0 & 0,024 & 0 & 0 & 0,155 & \\
\hline 0 & 0,000 & 0 & 0 & 0,028 & 0 & 0 & 0,024 & 0 & 0,155 & \multirow[b]{2}{*}{0,268} \\
\hline 0 & 0 & 0,000 & 0 & 0 & 0,028 & 0 & 0 & 0,024 & 0,155 & \\
\hline \multirow[t]{4}{*}{0,095} & 0,095 & 0,095 & 0,044 & 0,044 & 0,044 & 0,024 & 0,024 & 0,024 & & \\
\hline & & & & & & & & \multicolumn{2}{|c|}{ Average STD: } & 0,383 \\
\hline & & & & & & & & \multicolumn{3}{|c|}{ Note: All calculations are made in metres ( $m$ ) } \\
\hline & & & & & & & & & & \\
\hline
\end{tabular}

Tab. 2: Calculation of an average standard deviation of 12 pairs of corresponding point entities transformation.

For comparison reasons, an average standard deviation of the transformed points system (cloud) transformation made in the Geomagic Studio program was added to the calculated average standard deviation of 12 pairs of corresponding points transformation.
In the Geomagic Studio program, the calculated average standard deviation of all transformed points system (cloud) transformation amounts to $0.37 \mathrm{~m}$, which fully corresponds to the value of the standard deviation obtained for 12 selected pairs of points.

\section{CONCLUSIONS}

On the basis of comparison of a transformed system (cloud) of points and a reference system (cloud) - Kraški rob wall, and a comparison of calculations of average standard deviations of 12 pairs of corresponding points transformation as well as a transformation of the whole system (cloud) of transformed points it has been established that the rock block whereon the Črni kal castle is located once appertained to the Kraški rob wall wherefrom it broke off and slid down later on. The slide makes part of rock block failures (Kamelov et al. 1977; Ribičič 2003), which happen when a stiff rock block (in our case the Črni kal rock block made of limestone) slides along a soft plastic basis (in our case tectonically destroyed flysch marls and sandstones). Small deviations in the differ- ences between surfaces after transformation of the Črni kal rock block back into its original position being that of the Kraški rob wall show as well that for several centuries physical disintegration of limestone walls has made a very slow progress. Further examinations will be directed into rigorous and impartial assessment of transformation as well as into an analysis of other geological structural and engineering survey data, which shall enable even better understanding of the mechanism of a slide of the Črni kal rock block as one of the very rare natural equilibrium loss phenomena.

It has been proved as well that the method of professional selection of corresponding pairs of points as well as the calculation made by 12 - parameters affine trans- 


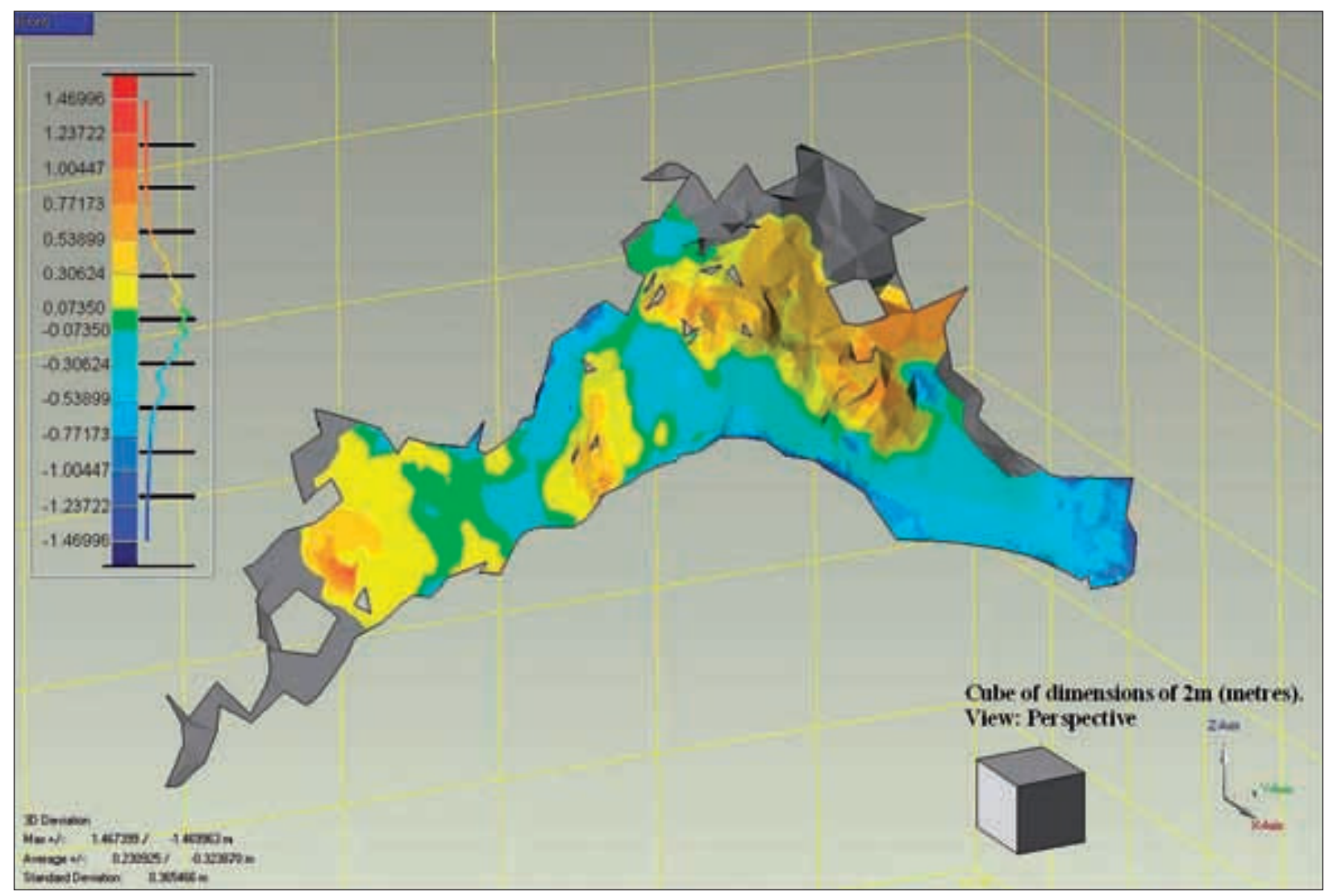

Fig. 11: Average standard deviation of a cloud of all transformed points made in the Geomagic Studio program. Note: All values in histogram are in metres.

formation method, which is technically and as regards calculation much easily performable, gives a very good approximation of the actual state which was proved by transformation of both clouds with 3822 points all to- gether, obtained by laser measurements and calculated by the Geomagic Studio program. The application of two different calculation methods provides enhanced reliability and mutual control.

\section{ACKNOWLEDGEMENTS}

We would like to express our thanks to the company of Geodetic Institute Celje d.o.o., which enabled $3 \mathrm{D}$ terrestrial laser scanning and to the company of DFG
Consulting d.o.o. for their assistance in Geomagic Studio software application. 


\section{REFERENCES}

Kamelov, B., Iliev, I. \& E. Avramova-Tacheva, 1977: Conditions for the origin, mechanism and dynamics of block landslides in Bulgaria.- Symposium - Landslides and other Mass Movements, 98-101, Bulgaria.

Konič, S., 2008: A contribution to the verification of rockblock slide with the model of point cloud transformation:- Unpublished PhD thesis.- Faculty of Natural Sciences and Engineering, p. 115, Ljubljana.

Vulić, M., 2008a: Transformation of point clouds.- [Online]. Available from: www.geo.ntf.uni lj.si/mvulic/ gradiva/ujemanje_oblakov_tock_MNK.pdf [Accessed: $3^{\text {rd }}$ July 2008].

Vulić, M., 2008b: Transformation of points.- [Online]. Available from: www.geo.ntf.uni lj.si/mvulic/gradiva/pred071029_def_af_transf_v04.pdf [Accessed: $3^{\text {rd }}$ July 2008].

Placer, L., 2007: Kraški rob: geološki prerez vzdolž AC Kozina - Koper.- Geologija, 50, 1, 29-44, Ljubljana.

Ribičič, M., 2003: Calculation of the Moving Landslide Masses Volume from Air Images.- Geologija, 46, 2, 413-418, Ljubljana.

Ribičič, M., 2004: Engineering geology II.- Faculty of Natural Sciences and Engineering, Department of Geology, p.126, Ljubljana.
Riegl Laser Measurement Systems, 2008: RLMS: Products: Terrestrial Scanning: LMS-Z420i.- [Online]. Available from: http://www.riegl.com/ [Accessed $5^{\text {th }}$ January 2008].

Toth, C. K. \& J. Shan, 2008: Topographic Laser Ranging and Scanning: Principles and Processing.- CRC Press, p. 608, New York.

Vižintin, G., Stevanovič, L. \& Ž. Vukelič, 2008: Development of environmental criteria for estimation of land development using GIS.- RMZ-mater. geoenviron., 55, 2, 237-258, Ljubljana.

Vulić, M., 2006/2007: Interna predavanja. Določanje parametrov 12 parametrične afino transformacije $\mathrm{z}$ MNK, p.14, Ljubljana.

Vulić, M., 2007a: Določanje ujemanja oblakov točk $z$ 12 parametrično afino preslikavo.- Naravoslovnotehniška fakulteta, Oddelek za geotehnologijo in rudarstvo, Ljubljana.

Vulić, M., 2007b: Metoda najmanjših kvadratov.- Naravoslovnotehniška fakulteta, Oddelek za geotehnologijo in rudarstvo, Ljubljana. 